\title{
Ammoniated babassu palm hay in anglo-nubian goat diets
}

\author{
Feno de pindoba de babaçu amonizado na dieta de caprinos anglo-nubianos
}

\author{
Antonia Leidiana Moreira ${ }^{1 *}$, Arnaud Azevêdo Alves ${ }^{1}$, Miguel Arcanjo Moreira Filho ${ }^{2}$, \\ Daniel Cézar da Silva³, Bruno Spíndola Garcez¹, Vânia Rodrigues Vasconcelos ${ }^{1}$
}

\author{
${ }^{1}$ Universidade Federal do Piauí/UFPI, Departamento de Zootecnia, Teresina, PI, Brasil \\ ¿Universidade Federal do Maranhão/UFMA, Centro de Ciências Agrárias e Ambientais, Chapadinha, MA, Brasil \\ ${ }^{3}$ Instituto Federal de Educação, Ciência e Tecnologia da Paraíba, Campus Sousa, Sousa, PB, Brasil \\ *Corresponding author: leda.vet@hotmail.com \\ Received in March 14, 2016 and approved August 8, 2016
}

\begin{abstract}
Leaves of babassu may be used in diets for goats under maintenance, however, it is a low-quality roughage due to its high fiber content. The chemical treatment by ammonia causes reduction in the proportion of the cell wall, in addition to providing non-protein nitrogen for the microbial protein synthesis in the rumen. Babassu palm hay ammoniated with $4 \%$ urea $\left(\mathrm{BHA}_{\mathrm{u} 4 \%}\right)$ was evaluated in this study as a substitute for guinea grass hay in the maintenance diets of goats in terms of intake, digestibility in vivo, and the partitioning of energy and nitrogen compounds. Twenty Anglo-Nubian male goats were used in a randomised block design with four treatments (diets containing $0,33,66$, or $100 \%$ BHA $\mathrm{A}_{4 \%}$ ) and five replicates (animals/block). The chemical compositions of the feeds, leftovers, faeces, nitrogen and crude energy of the urine were evaluated. In addition, the rumen fluid $\mathrm{pH}$, the rumen $\mathrm{N}-\mathrm{NH}_{3}$, and the blood serum urea were evaluated. The digestibility of the dry matter (DM), organic matter (OM), crud protein (CP), neutral detergent fiber (NDFap) and detergent acid (ADFap), corrected for ash and protein, declined (P<0.05) $0.0939,0.0722,0.0953,0.1113$, and $0.2666 \%$, respectively, with the $1 \%$ inclusion of babassu palm hay in the diet. A negative linear effect $(P<0.05$ ) was observed in the ingested nitrogen $(\mathrm{N})$, excretion of $\mathrm{N}$ in the urine, retained $\mathrm{N}$, and $\mathrm{N}$ balance, with decreases of $0.15711,0.0225$ and 0.1071 g/day and $0.1388 \%$, respectively, per percentage unit of the babassu palm hay included in the diet. The intake and digestibility of the DM and nutrients are reduced with the inclusion of $\mathrm{BHA}_{\mathrm{U} 4 \%}$ in maintenance diets for goats, with positive nitrogen balance and stability of the ruminal $\mathrm{pH}$ and $\mathrm{N}-\mathrm{NH} 3$ as well as blood urea, which presented values within the normal physiological range for goats.
\end{abstract}

Index terms: Digestibility in vivo; guinea grass; native forage; nitrogen balance; Orbignya phalerata Mart.

\begin{abstract}
RESUMO
Folhas de babaçu podem ser utilizadas em dietas para cabras em manutenção, no entanto, é um volumoso de baixa qualidade devido ao seu elevado teor de fibra. O tratamento químico por amônia provoca redução na proporção de parede celular, além de fornecer nitrogênio não-proteico para a síntese de proteína microbiana no rúmen. Avaliou-se a inclusão do feno de pindoba de babaçu amonizado com $4 \%$ de ureia em substituição ao feno de capim-colonião em dietas para caprinos em mantença, quanto ao consumo, digestibilidade in vivo e balanço energético e de compostos nitrogenados. Foram utilizados 20 caprinos machos da raça Anglonubiana, em delineamento experimental em blocos ao acaso com 4 tratamentos (dietas com 0, 33, 66 e 100\% de feno de pindoba amonizado com 4\% de ureia) e cinco repetições (animais/ blocos). Avaliou-se a composição química dos ingredientes, sobras e fezes e o $\mathrm{N}$ e a energia da urina. Avaliou o $\mathrm{pH}$ e $\mathrm{N}-\mathrm{NH} \mathrm{H}_{3}$ amoniacal do líquido ruminal e a ureia do sangue. A digestibilidade da MS, MO, PB, FDNcp e FDAcp reduziu $(P<0,05) 0,0939 ; 0,0722 ; 0,0953 ; 0,1113 ; 0,2666 \%$, respectivamente, a cada $1 \%$ de inclusão do feno de pindoba na dieta. O feno de pindoba de babaçu reduziu $(P<0,05)$ o $N$ ingerido, excretado na urina, o $\mathrm{N}$ retido e o balanço de nitrogênio, em 0,15711; 0,0225 and 0,1071 g/day and 0,1388\%, respectivamente, a cada 1\% de 1\% de inclusão do feno de pindoba na dieta. O consumo e a digestibilidade da MS e nutrientes são reduzidos com a inclusão do feno de pindoba de babaçu amonizado com $4 \%$ de ureia para caprinos em manutenção, com balanço de nitrogênio positivo e estabilidade do pH e N-NH3 do líquido ruminal e ureia do sangue, apresentando valores dentro da faixa fisiológica normal para caprinos.
\end{abstract}

Termos para indexação: Digestibilidade in vivo; capim colonião; forrageira nativa; balanço de nitrogênio; Orbignya phalerata Mart.

\section{INTRODUCTION}

To overcome the forage seasonality in the Mata dos Cocais area (Brazilian transitional interspace between the Amazon forest and the Caatinga biome), leaves of palm trees, e.g., the babassu, can be used for maintenance diets in goats, offering a promising alternative because of the low cost and stability as green forage that is available all year (Garcez et al., 2014).
Despite the advantages in terms of cost and availability, the babassu palm is a low-quality roughage feed, according to Moreira Filho and Oliveira (2008), due to its fiber content (70.55\% NDF and $48.38 \% \mathrm{ADF}$ ). Thus, the ammoniation process is an easy and low-cost alternative for improving its nutritional value.

The cellulose and hemicellulose are organised in an arrangement in the presence of lignin, which reduces the 
efficiency of hydrolysis of these compounds because of the difficulty that microorganisms experience in reaching them. The chemical treatment by ammonia causes a reduction in the proportion of the cell wall by the solubilisation of the hemicellulose and breaking of lignocellulosic bonds, in addition to supplying non-protein nitrogen for the microbial protein synthesis (Zanine et al., 2007).

The objective of this research was to evaluate the nutritional value for the intake and digestibility of the DM and nutrients, the balance of nitrogen compounds, and the rumen and blood parameters for the maintenance of goats fed diets containing babassu palm hay ammoniated with urea.

\section{MATERIAL AND METHODS}

The experiment was conducted at the Department of Animal Science of the Centre for Agricultural Sciences at the Federal University of Piauí (DZO/CCA/UFPI) in Teresina, PI. The leaves (leaflets + petiole) were collected from babassu trees approximately two metres in height and two years old, in an area of DZO/CCA/UFPI. The leaves were ground in a forage shredder machine and dried in the sun for $24 \mathrm{~h}$. The hay was ammoniated with urea in the proportion of $4 \%$ of the dry matter (DM).
For the ammoniation, the urea was dissolved in water to achieve a $30 \%$ moisture content in the hay (Gobbi et al., 2005) and then was applied evenly on the hay with a watering can. The treated hay was properly conditioned in an open and airy space on wooden pallets and sealed with plastic canvas. After 35 days under the activity of the ammonia, the canvas was removed, and the ammoniated hay was aerated for $48 \mathrm{~h}$ to eliminate the excess ammonia.

Diets were isofibrous, containing $0,33,66$, or $100 \%$ $\mathrm{BHA}_{\mathrm{U} 4 \%}$ as a substitute for guinea grass hay (Panicum maximum cv. colonião) harvested at 30 days of regrowth (Table 1), which composed the roughage part of the total maintenance diets for the goats, with a roughage:concentrate ratio of 70:30 (Table 2), formulated according to the NRC (2007).

Twenty uncastrated male goats of the AngloNubian breed, with an average weight of $34.31 \pm 10.25$ $\mathrm{kg}$ and in a good sanitary and nutritional state, were kept in metabolic cages with access to the diets, which were supplied at $0800 \mathrm{~h}$ and $1600 \mathrm{~h}$ and prepared to provide $20 \%$ leftovers. Water and mineral supplements were available ad libitum. Goats were weighed after a solid-feed deprivation period of $12 \mathrm{~h}$ before the distribution of the treatments in the experimental period and on the first and last days of the collection phase.

Table 1: Chemical composition of the diet ingredients.

\begin{tabular}{lrrrrc}
\hline \multicolumn{1}{c}{ Item } & GGH & BHA $_{\mathrm{U4} \%}{ }^{*}$ & Grain corn & Soybean meal & Urea \\
\hline Dry matter & 87.00 & 85.39 & 90.50 & 91.21 & 100.00 \\
\% of the DM & & & & & \\
Organic matter & 92.13 & 95.51 & 98.76 & 93.04 & - \\
Crude protein & 9.21 & 17.35 & 8.72 & 49.58 & 281.25 \\
Ether extract & 1.09 & 2.20 & 4.14 & 0.91 & - \\
NDFap & 63.96 & 66.89 & 10.98 & 14.35 & - \\
ADFap & 42.18 & 44.08 & 4.62 & 9.77 & - \\
Hemicellulose & 21.78 & 22.81 & 6.36 & 4.58 & - \\
Cellulose & 37.27 & 31.78 & 3.59 & 8.31 & - \\
Lignin & 4.91 & 12.30 & 1.03 & 1.46 & - \\
NFC & 17.87 & 11.91 & 74.92 & 28.20 & - \\
$\quad \%$ of the total N & & & & & - \\
NDIN & 35.77 & 30.99 & 3.75 & 5.70 & - \\
ADIN & 21.52 & 15.77 & 1.57 & 2.71 & -
\end{tabular}

GGH (guinea grass hay); $B H A_{U 4 \%}$ (babassu palm hay ammoniated with $4 \%$ urea, in \% DM).

*Chemical composition of babassu palm hay (not ammoniated): $91.01 \%$ dry matter and in this $\%$ of dry matter, $94.72 \%$ organic matter, $12.08 \%$ crude protein, $95 \%$ ether extract, $70.55 \%$ neutral detergent fiber, $48.38 \%$ acid detergent fiber, $22.17 \%$ hemicellulose, $35.47 \%$ cellulose, $12.91 \%$ lignin, and $11.04 \%$ non-fibrous carbohydrates and in the $\%$ of the total nitrogen, $39.90 \%$ nitrogen neutral detergent and $20.44 \%$ nitrogen acid detergent. 
Table 2: Centesimal and chemical composition of the diets.

\begin{tabular}{|c|c|c|c|c|}
\hline \multirow{2}{*}{ Ingredient/nutrient } & \multicolumn{4}{|c|}{$\mathrm{BHA}_{\mathrm{U} 4 \%}(\%$ of $\mathrm{CGH})$} \\
\hline & 0 & 33 & 66 & 100 \\
\hline \multicolumn{5}{|c|}{ Centesimal composition } \\
\hline GGH & 70.21 & 46.55 & 23.33 & 0.00 \\
\hline $\mathrm{BHA}_{\mathrm{U} 4 \%}$ & 0.00 & 23.28 & 46.67 & 70.00 \\
\hline Ground corn grain & 23.91 & 25.44 & 25.51 & 26.78 \\
\hline Soybean meal & 5.07 & 4.45 & 4.46 & 3.19 \\
\hline Urea & 0.77 & 0.25 & 0.00 & 0.00 \\
\hline Sul & 0.04 & 0.03 & 0.03 & 0.03 \\
\hline \multicolumn{5}{|c|}{ Chemical composition } \\
\hline Dry matter & 88.16 & 87.74 & 87.33 & 86.95 \\
\hline \multicolumn{5}{|l|}{$\% D M$} \\
\hline Organic matter & 93.02 & 94.39 & 95.41 & 96.27 \\
\hline Crude protein & 13.23 & 13.45 & 14.68 & 16.06 \\
\hline NDFap & 48.26 & 48.78 & 49.58 & 50.22 \\
\hline ADFap & 31.21 & 31.51 & 32.03 & 32.40 \\
\hline Hemicellulose & 17.04 & 17.27 & 17.55 & 17.82 \\
\hline Cellulose & 27.45 & 26.03 & 24.81 & 23.47 \\
\hline Lignin & 3.77 & 5.48 & 7.21 & 8.93 \\
\hline Total carbohydrates & 80.15 & 80.18 & 79.68 & 79.52 \\
\hline NFC & 31.89 & 31.41 & 30.10 & 29.30 \\
\hline \multicolumn{5}{|l|}{ \%of the total N } \\
\hline NDIN & 26.30 & 25.07 & 24.02 & 22.88 \\
\hline ADIN & 15.62 & 14.21 & 12.90 & 11.55 \\
\hline
\end{tabular}

GGH (guinea grass hay); $B H A_{U 4 \%}$ (babassu palm hay ammoniated with $4 \%$ urea, in $\%$ DM).

The experimental period was fifteen days, with five days for the evaluation of intake and collection of leftovers, faeces, and urine and one day to collect the rumen fluid (RF) and blood; this period was preceded by nine days for the animals to acclimate to the facilities, management, and diets. Leftovers, faeces, and urine were collected before each meal, and aliquots of $20 \%$ were taken, conditioned in plastic bags and bottles, and stored at -5 to $-10^{\circ} \mathrm{C}$. The daily intake of DM and nutrients was determined as the difference between the feed supplied and the leftovers.

The concentrations of DM were determined, and the $\mathrm{CP}, \mathrm{EE}, \mathrm{MM}$, and GE were calculated on the basis of those concentrations. The NDF and ADF values, corrected for ash and protein (NDFap and ADFap), were obtained according to the methodologies of Association of Official Agricultural
Chemists - AOAC (2012), and the lignin content was determined by the method of Van Soest et al. (1991), adapted for the use of fabric bags (TNT - $100 \mathrm{~g} / \mathrm{m}^{2}$ ) (Valente et al., 2011). NDIN and ADIN were obtained based on the total N, as described by Licitra, Hernandez and Van Soest (1996).

The concentrations of OM, CEL, and HEM were calculated by the following formulae: $O M=100-M M$, $C E L=A D F a p-L I G$, and HEM =NDFap - ADFap . The NFC and TC contents were estimated using the formulae proposed by Detmann and Valadares Filho (2010): NFC $=100-\left[\left(\% C P-\% C P_{\text {urea }}+\%\right.\right.$ urea $)+\% N D F a p+\% E E+$ $\% M M]$ and $T C=N F C+N D F a p$, where $\% \mathrm{CP}=$ the dietary crude protein, $\% \mathrm{CP}_{\text {urea }}=$ the $\mathrm{CP}$ from the urea in the diet, and $\%$ urea $=$ the percentage of urea in the diet. The TDN content was calculated by the formula proposed by Weiss, Conrad and Pierre (1992), as follows: $T D N(\%)=D C P \%$ $+D N D F \%+D N F C \%+(2.25 \times \mathrm{DEE} \%)$.

The nitrogen and GE in the urine were evaluated according to AOAC (2012), and the loss of energy as methane gas (EG) was estimated by the formula proposed by Blaxter and Clapperton (1965): $\mathrm{Cm}=3.67+0.062 \mathrm{D}$, where $\mathrm{Cm}=$ the methane production $(\mathrm{kcal} / 100 \mathrm{kcal}$ of consumed energy) and $\mathrm{D}=$ the apparent digestibility of GE.

The digestibility was determined by the method of total collection in vivo of $\mathrm{DM}, \mathrm{CP}, \mathrm{EE}, \mathrm{OM}, \mathrm{NDF}, \mathrm{ADF}$, HEM, CEL, NFC, TC, and GE by the following formula: $\operatorname{Dig}(\%)=\left[\left(N_{1}-N_{\mathrm{f}}\right) \div N_{1}\right] \times 100$, where $\mathrm{N}_{\mathrm{I}}=$ the nutrient ingested, and $\mathrm{N}_{\mathrm{F}}=$ the nutrient in the faeces. The nitrogen balance (NB) was determined by the following equation: $N B(\%)=\left[N_{\text {ingested }}-\left(N_{\text {feces }}+N_{\text {urine }}\right) \div N_{\text {ingested }}\right] \times 100$.

The ME was estimated by subtracting the urinary and gas losses (EG) from the DE. The metabolisability of the energy (q) was calculated by the $q=M E / G E$ ratio. The efficiency of the use of ME for maintenance $\left(\mathrm{k}_{\mathrm{m}}\right)$ was estimated with the equation proposed by AFRC (1993): $k_{m}=0.503+0.35 q$.

Samples of rumen fluid (RF) and blood were collected on the $13^{\text {th }}$ experimental day. The RF was collected using an oesophageal tube bound to a vacuum pump, according to Silva et al. (2010), and the pH was determined immediately with a digital $\mathrm{pH}$ metre. Samples of RF were filtered through four layers of gauze and conditioned in plastic bottles containing $1.0 \mathrm{~mL} \mathrm{1:1(6.0}$ N) $\mathrm{HCl}$ and preserved at -5 to $-10{ }^{\circ} \mathrm{C}$. The concentration of $\mathrm{N}_{-} \mathrm{NH}_{3}$ was determined as described by Nogueira and Souza (2005). Blood was collected from the jugular vein into Vacutainer tubes, which were centrifuged to allow subsequent determination of the concentration of the serum urea with the Urea EC enzymatic colorimetric test (Labtest 1999). 
The data were analysed in a completely randomised block (animals) design, adopting mixed models, with the treatments (diets) considered as a fixed effect and the block (animals) and the residual as random effects, by the MIXED procedure of SAS (2002). The analyses of the data of $\mathrm{pH}$ and $\mathrm{N}-\mathrm{NH}_{3}$ of the rumen fluid and blood serum urea followed an arrangement of split-plots in time (collection time), with the comparison of various covariance structures for the residues. When the diet, the time, or the diet $\times$ time interaction were significant, the significance of the linear, quadratic, or cubic beta parameters was evaluated, and the regression equation was fitted by the PROC MIXED procedure of SAS (2002) at a probability level of $\mathrm{P} \leq 0.05$.

\section{RESULTS AND DISCUSSION}

The inclusion of the babassu palm hay ammoniated with $4 \%$ urea $\left(\mathrm{BHA}_{\mathrm{U} 4 \%}\right)$ as a substitution for guinea grass hay in the maintenance diets of goats resulted in a decrease $(\mathrm{P}<.05)$ in the intake of dry matter $(\mathrm{DMI})$, organic matter (OMI), crude protein (CPI), neutral detergent fiber (NDFI), cellulose (CELI), total carbohydrates (TCI), nonfiber carbohydrates (NFCI), and total digestible nutrients (TDNI) (Table 3).

The reduction in the dietary DMI with the inclusion of babassu palm hay may be associated with the high percentages of NDF and ADF in its composition, in addition to the high levels of lignin in the fibrous fraction, given that large proportions of fibrous components lead to a longer retention of the digesta in the rumen, which negatively affects the availability of nutrients and their intake, as a result of their slow and incomplete degradation.

Although the DMI of the diets containing ammoniated babassu palm hay did not correspond to the $940 \mathrm{~g} /$ day of DM established by the NRC (2007) as the requirement for the maintenance of goats weighing 35 $\mathrm{kg}$ with weight gain of $25 \mathrm{~g} /$ day, the energy (TDNI) and protein (CPI) requirements were met, at $460 \mathrm{~g} / \mathrm{d}$ and 42 $\mathrm{g} / \mathrm{d}$, respectively.

When roughage is ammoniated with urea, it shows a relative increase in digestibility due to the action of ammonia on the cell wall components. Ammonia acts on the molecules of hemicellulose by breaking the chemical bonds and causing partial solubilisation of this component, thereby facilitating the activity of ruminal microorganisms with an increased DM intake (Gobbi et al., 2005). This behaviour was not demonstrated in the current study, probably due to the negative effect of the elevated lignin content of the babassu palm hay (12.91\% of the DM in the babassu palm hay that was not ammoniated compared to
$12.30 \%$ of the DM in the $\mathrm{BHA}_{\mathrm{U} 4 \%}$ ) on the digestibility of the fibrous fraction, which negatively affected the intake.

The decrease in the OMI, NFCI and TDNI may have influenced the DMI because, according to Schmidt et al. (2003), the DMI for animals is not influenced by treatment of the forage with urea, but decreases with the deficit in readily available energy.

The CPI decreased $(\mathrm{P}<.05)$ with an increase of $0.0349 \mathrm{~g} / \mathrm{LW}^{0.75}$ per percentage unit of inclusion of babassu palm hay in the diet. Therefore, to equate or increase the CPI from the diets or even to increase the levels of CP in the diets was impossible (Table 2).

The reduction in the intakes of $\mathrm{OM}, \mathrm{NFC}$, and TDN is related to the lower DMI, which has a consequence on the energy available in the diet. Similar results were obtained by Agy et al. (2012), and this response may be attributed to the increase in the dietary ADF content (Table 2). However, all diets resulted in all requirements of the NRC (2007) for $35 \mathrm{~kg}$ goats with a weight gain of $25 \mathrm{~g} /$ day being met (PD at $42 \mathrm{~g} /$ day, NFC at $338.4 \mathrm{~g} / \mathrm{day}$, and TDN at $49 \% \mathrm{DM})$. Additionally, the NDF and ADF intakes (46.66 and 31.35\%) met the values established by NRC (2001) for adequate cellulolytic microbial activity in the rumen.

The NDFI declined $(\mathrm{P}<.05)$ with an increase of $0.1353 \mathrm{~g} / \mathrm{LW}^{0.75}$ per percentage unit of babassu palm hay included in the diet, and NDF also declined, which is related to the low DM intake. The NDF intake was close to the 0.8 to $1.2 \%$ LW suggested by Van Soest (1994), which may be higher when the diet has a low energy density.

The addition of ammoniated babassu palm hay as a substitute for guinea grass hay resulted in a reduction $(\mathrm{P}<.05)$ in the digestibility of the dry matter $(\mathrm{DDM})$, organic matter (DOM), crude protein (DCP), neutral detergent fiber (DNDF), acid detergent fiber (DADF), cellulose (DCEL), and total carbohydrates (DTC) and in the gross energy (GE), digestible energy (DE), metabolisable energy (ME), coefficient of metabolisability of the energy (q), and efficiency of use of ME for maintenance (Efic) (Table 4).

The DMD decreased as the babassu palm hay was added to the diet, which is related to the high NDF and lignin contents present in this ingredient. However, the average DMD values surpassed the 60.59 to $64.16 \%$ obtained by Calixto Júnior et al. (2007), who included $50 \%$ stargrass hay ammoniated with 0 and $4 \%$ urea, respectively, in the total diets for sheep.

Each percentage unit of babassu palm hay added to the diet caused a reduction $(\mathrm{P}<.05)$ of $0.0953 \%$ in $\mathrm{CPD}$, 
which is a different effect than that obtained by Calixto Júnior et al. (2007), who reported a quadratic effect for CPD, with increases starting with $2.05 \%$ inclusion of the stargrass hay in sheep diets. A decrease in the CPD was observed herein, even with increased dietary $\mathrm{CP}$ with the inclusion of the $\mathrm{BHA}_{\mathrm{U} 4 \%}$ because of the decrease in the DMD.

Table 3: Intake of dry matter and nutrients by goats fed diets containing babassu palm hay ammoniated with $4 \%$ urea, as \% DM (BHA $\left.\mathrm{U}_{4 \%}\right)$, as a substitution for guinea grass hay.

\begin{tabular}{|c|c|c|c|c|c|c|c|c|}
\hline \multirow{2}{*}{ Parameter } & \multicolumn{4}{|c|}{$\mathrm{BHA}_{\mathrm{U} 4 \%}$ level (\%) } & \multirow{2}{*}{$\begin{array}{c}\text { Regression } \\
\text { equation }\end{array}$} & \multirow{2}{*}{ SEM } & \multicolumn{2}{|c|}{ Significance } \\
\hline & 0 & 33 & 66 & 100 & & & Linear & Quadratic \\
\hline DM (g/day) & 947.61 & 709.26 & 570.74 & 562.03 & 1 & 53.57 & 0.0001 & 0.4745 \\
\hline DM (\% LW) & 2.81 & 2.15 & 1.72 & 1.64 & 2 & 0.15 & 0.0002 & 0.5234 \\
\hline $\mathrm{DM}\left(\mathrm{g} / \mathrm{LW}^{0.75}\right)$ & 66.82 & 51.14 & 40.91 & 38.82 & 3 & 3.07 & $<0.0001$ & 0.4942 \\
\hline OM (g/day) & 892.60 & 677.53 & 551.06 & 547.46 & 4 & 49.59 & 0.0002 & 0.5200 \\
\hline OM (\%LW) & 2.65 & 2.05 & 1.66 & 1.61 & 5 & 0.14 & 0.0003 & 0.5567 \\
\hline $\mathrm{OM}\left(\mathrm{g} / \mathrm{LW}^{0.75}\right)$ & 63.00 & 48.82 & 39.52 & 37.92 & 6 & 2.81 & $<0.0001$ & 0.5364 \\
\hline CP (g/day) & 132.86 & 100.00 & 86.34 & 89.35 & 7 & 7.09 & 0.0904 & 0.0006 \\
\hline CP $(\% \mathrm{LW})$ & 0.40 & 0.30 & 0.26 & 0.25 & 8 & 0.02 & 0.0020 & 0.4163 \\
\hline $\mathrm{CP}\left(\mathrm{g} / \mathrm{LW} \mathrm{W}^{0.75}\right)$ & 9.44 & 7.20 & 6.21 & 6.19 & 9 & 0.41 & 0.0004 & 0.3921 \\
\hline EE (g/day) & 19.53 & 17.85 & 17.17 & 19.59 & $\hat{y}=18.54$ & 0.94 & 0.2392 & 0.7912 \\
\hline NDFap (g/day) & 431.60 & 325.14 & 259.48 & 262.24 & 10 & 24.72 & 0.0548 & 0.0002 \\
\hline NDFap (\% LW) & 1.28 & 0.99 & 0.78 & 0.76 & 11 & 0.07 & 0.0002 & 0.5605 \\
\hline NDFap (g/ LW0.75) & 30.38 & 23.43 & 18.61 & 17.87 & 12 & 1.39 & $<0.0001$ & 0.5494 \\
\hline ADF (g/day) & 292.36 & 221.47 & 179.28 & 176.18 & 13 & 16.87 & 0.0002 & 0.5308 \\
\hline HEM (g/day) & 139.12 & 103.68 & 80.20 & 85.94 & 14 & 7.95 & 0.4870 & 0.0002 \\
\hline CEL (g/day) & 250.63 & 174.87 & 126.26 & 110.43 & 15 & 16.59 & $<0.0001$ & 0.3657 \\
\hline TC (g/day) & 766.51 & 571.88 & 457.88 & 454.00 & 16 & 43.37 & 0.0001 & 0.4536 \\
\hline NFC (g/day) & 334.91 & 246.83 & 198.40 & 191.72 & 17 & 18.73 & $<0.0001$ & 0.3894 \\
\hline TDN (g/day) & 666.16 & 486.59 & 382.66 & 372.22 & 18 & 38.52 & $<0.0001$ & 0.4620 \\
\hline TDN (\%LW) & 1.99 & 1.48 & 1.16 & 1.06 & 19 & 0.11 & 0.0001 & 0.5090 \\
\hline TDN (g/LW $\left.{ }^{0.75}\right)$ & 47.25 & 35.19 & 27.49 & 24.87 & 20 & 2.40 & $<0.0001$ & 0.4786 \\
\hline
\end{tabular}

$D M$ (dry matter); OM (organic matter); CP (crude protein); $E E$ (ether extract); NDFap (neutral detergent fiber corrected for ash and protein); ADFap (acid detergent fiber corrected for ash and protein); HEM (hemicellulose); CEL (cellulose); TC (total carbohydrates); NFC (non-fiber carbohydrates); TDN (total digestible nutrients); SEM (standard error of the mean).

${ }^{1} \hat{y}=900.98-4.3571 X . R^{2}=0.5322$

${ }^{2} \hat{y}=2.6834-0.0126 X . R^{2}=0.5373$

${ }^{3} \hat{y}=63.867-0.3004 X . R^{2}=0.6921$

${ }^{4} \hat{y}=850.11-3.924 X . R^{2}=0.4524$

${ }^{5} \hat{y}=2.5334-0.0113 X . R^{2}=0.5074$

${ }^{6} \hat{y}=60.288-0.2701 X . R^{2}=0.6670$

$7 \hat{y}=132.6-1.2158 X+0.0076 X^{2} \cdot R^{2}=0.4337$

$8 \hat{y}=0.3756-0.0015 X \cdot R^{2}=0.3885$

${ }^{9} \hat{y}=8.9199-0.0349 X . R^{2}=0.5204$

${ }^{10} \hat{y}=432.31-4.036 X+0.022 X^{2} \cdot R^{2}=0.5102$

$$
\begin{aligned}
& { }^{11} \hat{y}=1.2211-0.0057 X \cdot R^{2}=0.5378 \\
& { }^{12} \hat{y}=29.07-0.1353 X \cdot R^{2}=0.6846 \\
& { }^{13} \hat{y}=278.98-1.3254 X \cdot R^{2}=0.4461 \\
& { }^{14} \hat{y}=139.75-1.428 X+0.0084 X^{2} \cdot R^{2}=0.5377 \\
& { }^{15} \hat{y}=238.57-1.5443 X \cdot R^{2}=0.6260 \\
& { }^{16} \hat{y}=728.04-1.5453 X \cdot R^{2}=0.4834 \\
& { }^{17} \hat{y}=317.61-1.5861 X \cdot R^{2}=0.5182 \\
& { }^{18} \hat{y}=632.74-3.3562 X \cdot R^{2}=0.5485 \\
& { }^{19} \hat{y}=1.9015-0.01 X \cdot R^{2}=0.5610 \\
& { }^{20} \hat{y}=45.143-0.2371 X \cdot R^{2}=0.7065
\end{aligned}
$$


Table 4: Digestibility of dry matter and nutrients and energy balance of diets containing babassu palm hay ammoniated with $4 \%$ urea, as \% $\mathrm{DM}\left(\mathrm{BHA}_{\mathrm{U} 4 \%}\right)$, which was substituted for guinea grass hay for the maintenance of goats.

\begin{tabular}{|c|c|c|c|c|c|c|c|c|}
\hline \multirow{2}{*}{ Parameter } & \multicolumn{4}{|c|}{$\mathrm{BHA}_{\mathrm{U} 4 \%}(\%)$} & \multirow{2}{*}{$\begin{array}{l}\text { Regression } \\
\text { equation }\end{array}$} & \multirow{2}{*}{ SEM } & \multicolumn{2}{|c|}{ Significance } \\
\hline & 0 & 33 & 66 & 100 & & & Linear & Quadratic \\
\hline DM (\%) & 70.55 & 67.40 & 64.26 & 61.10 & 1 & 1.19 & 0.0071 & 0.4060 \\
\hline OM (\%) & 72.07 & 69.70 & 67.23 & 64.92 & 2 & 1.04 & 0.0131 & 0.4544 \\
\hline CP (\%) & 75.66 & 70.18 & 69.53 & 65.48 & 3 & 1.23 & 0.0038 & 0.7988 \\
\hline EE (\%) & 74.89 & 82.81 & 89.80 & 91.58 & 4 & 1.66 & $<0.0001$ & 0.0569 \\
\hline NDFap (\%) & 65.12 & 63.23 & 58.89 & 54.10 & 5 & 1.43 & 0.0061 & 0.2271 \\
\hline ADFap (\%) & 69.73 & 61.20 & 52.68 & 42.97 & 6 & 2.99 & 0.0353 & 0.0848 \\
\hline HEM (\%) & 41.42 & 46.32 & 40.69 & 26.57 & $\hat{y}=38.75$ & 2.77 & 0.0537 & 0.0710 \\
\hline CEL (\%) & 71.06 & 65.48 & 55.25 & 40.41 & 7 & 3.22 & 0.0003 & 0.2744 \\
\hline TC (\%) & 72.35 & 69.84 & 66.70 & 64.81 & 8 & 1.09 & 0.0135 & 0.4867 \\
\hline NFC (\%) & 81.64 & 78.55 & 76.85 & 78.27 & $\hat{y}=78.83$ & 0.83 & 0.0724 & 0.8266 \\
\hline CE (\%) & 69.23 & 65.01 & 62.98 & 58.72 & 9 & 1.34 & 0.0097 & 0.4198 \\
\hline TDN (\% DM) & 70.51 & 68.89 & 67.34 & 66.14 & $\hat{y}=68.22$ & 0.90 & 0.0589 & 0.5008 \\
\hline DE (Mcal/kgDM) & 3.01 & 2.82 & 2.74 & 2.55 & 10 & 0.06 & 0.0113 & 0.3886 \\
\hline ME (Mcal/kgDM) & 2.56 & 2.38 & 2.29 & 2.10 & 11 & 0.05 & 0.0108 & 0.3828 \\
\hline$q$ & 0.59 & 0.55 & 0.52 & 0.49 & 12 & 0.01 & 0.0098 & 0.4035 \\
\hline Efic & 0.71 & 0.69 & 0.68 & 0.66 & 13 & 0.004 & 0.0100 & 0.4040 \\
\hline
\end{tabular}

DM (dry matter); OM (organic matter); CP (crude protein); $E E$ (ether extract); NDFap (neutral detergent fiber corrected for ash and protein); ADFap (acid detergent fiber corrected for ash and protein); HEM (hemicellulose); CEL (cellulose); TC (total carbohydrates); NFC (non-fiber carbohydrates); TDN (total digestible nutrients); CE (crude energy); $D E$ (digestible energy); ME (metabolisable energy q (coefficient of metabolisability of the energy); Efic (efficiency of use of the ME for maintenance); SEM (standard error of the mean).

${ }^{1} \hat{y}=70.517-0.0939 X . R^{2}=0.4572$

${ }^{2} \hat{y}=72.064-0.0722 X . R^{2}=0.3539$

${ }^{3} \hat{y}=74.912-0.0953 X . R^{2}=0.4421$

${ }^{4} \hat{y}=76.179+0.1748 X . R^{2}=0.8087$

${ }^{5} \hat{y}=65.903-0.1113 X . R^{2}=0.4422$

${ }^{6} \hat{y}=69.911-0.2666 X . R^{2}=0.5828$

$7 \hat{y}=73.233-0.3026 X . R^{2}=0.6457$

The digestibility of NFC was $78.83 \pm 3.61 \%$, which is below the $82.96 \pm 9.82 \%$ obtained by Branco et al. (2010); this digestibility might have been a result of the lower quality of the forage utilised in this study. The increase in the proportion of cell wall (NDF) in the diets leads to decreased digestibility, except for the fiber, which is usually increased due to the greater activity of the cellulolytic bacteria in the rumen (Carvalho et al., 2006; Zhao et al., 2011). This did not occur in this experiment; instead, the NDFD and ADFD decreased when the babassu palm hay was added to the diet as a result of the high lignification of the cell wall (Garcez et al., 2014).

$$
\begin{aligned}
& { }^{8} \hat{y}=72.281-0.0778 X . R^{2}=0.3716 \\
& { }^{9} \hat{y}=68.989-0.1003 X . R^{2}=0.4124 \\
& { }^{10} \hat{y}=2.9967-0.0043 X . R^{2}=0.4143 \\
& { }^{11} \hat{y}=2.5511-0.0044 X . R^{2}=0.4622 \\
& { }^{12} \hat{y}=0.5873-0.001 X . R^{2}=0.4600 \\
& { }^{13} \hat{y}=0.7086-0.0004 X . R^{2}=0.4600
\end{aligned}
$$

The addition of babassu palm hay did not influence the dietary TDN, which was $66.22 \%$ on average, probably due to the low DMI and OMI, although it met the NRC (2007) maintenance requirements of $49 \% \mathrm{DM}$ for $35-\mathrm{kg}$ goats with a live weight gain of up $25 \mathrm{~g}$ /day.

Concerning the metabolisable energy, starting at $33 \%$ inclusion, the babassu palm hay does not meet the requirements established by the NRC (2007) for the maintenance of Anglo-Nubian goats. The lower efficiency of use of ME for maintenance and the lower coefficient of metabolisability of the energy (q) with the inclusion of babassu palm hay in the diets may be associated with 
the lower digestibility of the dietary NDF, which reduces the available energy from the cell wall for metabolism.

Regarding nitrogen metabolism, the inclusion of ammoniated babassu palm hay as a substitute for guinea grass hay in the diets resulted in a reduction $(\mathrm{P}<.05)$ of ingested $\mathrm{N}$, urinary $\mathrm{N}$, absorbed $\mathrm{N}$ and retained $\mathrm{N}$ (Table 5). This effect suggests a greater efficiency in the use of $\mathrm{N}$ with the inclusion of ammoniated babassu palm hay, coupled with increased NPN resulting from the treatment of this roughage with urea.

The ingested $\mathrm{N}$ and the urinary $\mathrm{N}$ were reduced $(\mathrm{P}<.05)$ with the inclusion of babassu palm hay, and this response was similar to that of the DMI (Table 3). However, faecal N showed a quadratic response $(\mathrm{P}<.05)$, different from the effect observed for the ingested $\mathrm{N}$, which, according to Branco et al. (2003), occurs because the animal's metabolism alters unstable sources of nitrogen in the body, making it difficult to maintain a balance between the ingested $\mathrm{N}$ and excreted N. Carro et al. (2012) obtained a high urinary excretion of $\mathrm{N}$ by goats and sheep when feeding them diets with a concentrate to roughage ratio of 70:30, which is justified by the greater absorption of $\mathrm{N}$ and consequent greater loss of this compound due to an imbalance in energy/protein in tissues.

An increase in the faecal N/urinary $\mathrm{N}$ ratio was observed for the inclusion of $52.8 \%$ ammoniated babassu palm hay in the diets, which demonstrated a greater effect on digestibility than the endogenous metabolism on the retention of $\mathrm{N}$ when this roughage was included. Proportional to the ingested N, a quadratic effect was observed in the faecal losses of $\mathrm{N}$ $(\mathrm{P}<.05)$ with the inclusion of babassu palm hay in the diets, which resulted in effect similar to the nitrogen balance (NB). The NB was positive for all diets, which indicates the ability of the babassu palm hay to supply the $\mathrm{N}$ required for the maintenance of goats, according to the NRC (2007), without $\mathrm{N}$ being mobilised from the body reserves and with limited excretion of the ingested $\mathrm{N}$.

The rumen fluid $\mathrm{pH}$ was not influenced $(\mathrm{P}>.05)$ by the diets containing the babassu palm hay ammoniated with $4 \%$ urea, averaging $7.02 \pm 0.11$ (Table 6). This value was similar to the $6.5 \pm 0.5$, which according to Moraes et al. (2010), is sufficient to ensure the adequate degradation of the fiber and access by the microorganisms to the dietary protein. The presence of urea did not compromise the stability of the nitrogen compounds in the rumen. The explanation could be that nitrogen is incorporated in the interior of the fiber cell wall to become less soluble in the rumen environment. This allows for equalisation in relation to the use of microbial nitrogen and energy from the fiber degradation.

Table 5: Nitrogen metabolism in goats fed diets containing babassu palm hay ammoniated with $4 \%$ urea, as $\%$ $\mathrm{DM}\left(\mathrm{BHA}_{\mathrm{U} 4 \%}\right)$, substituted for guinea grass hay.

\begin{tabular}{|c|c|c|c|c|c|c|c|c|}
\hline \multirow{2}{*}{ Parameter } & \multicolumn{4}{|c|}{$\mathrm{BHA}_{\mathrm{U} 4 \%}$ level (\%) } & \multirow{2}{*}{$\begin{array}{c}\text { Regression } \\
\text { equation }\end{array}$} & \multirow{2}{*}{ SEM } & \multicolumn{2}{|c|}{ Significance P } \\
\hline & 0 & 33 & 66 & 100 & & & Linear & Quadratic \\
\hline $\mathrm{I}_{\mathrm{N}}$ (g/day) & 21.26 & 16.00 & 13.81 & 14.30 & 1 & 1.55 & $<0.0001$ & 0.1461 \\
\hline $\mathrm{F}_{\mathrm{N}}$ (g/day) & 4.95 & 5.23 & 3.85 & 2.36 & 2 & 0.32 & 0.0681 & 0.0175 \\
\hline$U_{N}$ (g/day) & 3.52 & 2.67 & 1.54 & 1.42 & 3 & 0.24 & $<0.0001$ & 0.0762 \\
\hline $\operatorname{Abs}_{N}$ (g/day) & 16.31 & 10.77 & 9.96 & 11.94 & 4 & 1.27 & $<0.0001$ & 0.7339 \\
\hline $\mathrm{R}_{\mathrm{N}}$ (g/day) & 12.79 & 8.10 & 8.42 & 10.52 & 5 & 1.05 & $<0.0001$ & 0.2309 \\
\hline $\mathrm{F}_{\mathrm{N}} / \mathrm{I}_{\mathrm{N}}(\%)$ & 23.29 & 32.69 & 27.87 & 16.51 & 6 & 1.31 & 0.5465 & 0.0014 \\
\hline$U_{N} / I_{N}(\%)$ & 16.56 & 16.69 & 11.15 & 9.93 & 7 & 0.91 & 0.2405 & 0.0017 \\
\hline$F_{N} / U_{N}(g / g)$ & 1.41 & 1.96 & 2.50 & 1.66 & 8 & 0.16 & 0.2405 & 0.0032 \\
\hline NB $\left(\%\right.$ of $\left.I_{N}\right)$ & 60.16 & 50.63 & 60.98 & 73.57 & 9 & 1.57 & 0.0785 & 0.0283 \\
\hline
\end{tabular}

$I_{N}$ (ingested nitrogen); $F_{N}$ (faecal nitrogen); $U_{N}$ (urinary nitrogen); $A b s_{N}$ (absorbed nitrogen); $R_{N}$ (retained nitrogen); NB (nitrogen balance); SEM (standard error of the mean).

${ }^{1} \hat{y}=23.133-0.1571 X . R^{2}=0.9167$

$2 \hat{y}=5.0251+0.0102 X-0.0004 X^{2} \cdot R^{2}=0.7703$

${ }^{3} \hat{y}=3.4151-0.0225 X . R^{2}=0.7773$

${ }^{4} \hat{y}=17.7-0.1295 X . R^{2}=0.9275$

${ }^{5} \hat{y}=14.85-0.1071 X . R^{2}=0.9286$

$$
\begin{aligned}
& { }^{6} \hat{y}=5.4217+23.439 X-5.1908 X^{2} \cdot R^{2}=0.8704 \\
& 7 \hat{y}=16.272-0.1992+0.0023 X^{2} \cdot R^{2}=0.6307 \\
& { }^{8} \hat{y}=1.3448+0.0412 X-0.0004 X^{2} \cdot R^{2}=0.4492 \\
& { }^{9} \hat{y}=76.322-22.577 X+5.5267 X^{2} \cdot R^{2}=0.6947
\end{aligned}
$$


Table 6: The $\mathrm{pH}$ and ammoniacal nitrogen $\left(\mathrm{N}^{-\mathrm{NH}_{3}}\right)$ of the rumen fluid and blood plasma urea from goats fed diets containing babassu palm hay ammoniated with $4 \%$ urea, in \% $\mathrm{DM}\left(\mathrm{BHA}_{\mathrm{U} 4 \%}\right)$ when substituted for guinea grass hay.

\begin{tabular}{|c|c|c|c|c|c|c|c|c|c|}
\hline \multirow{2}{*}{ Parameter } & \multicolumn{4}{|c|}{$\mathrm{BHA}_{\mathrm{U4} \%}$ level (\%) } & \multicolumn{3}{|c|}{$\mathrm{P}$} & \multirow{2}{*}{ SEM } & \multirow{2}{*}{ RE time } \\
\hline & 0 & 33 & 66 & 100 & $\mathrm{D}$ & $\mathrm{T}$ & $\mathrm{D} \times \mathrm{T}$ & & \\
\hline $\begin{array}{c}\mathrm{pH} \\
\mathrm{mg} / \mathrm{dL}\end{array}$ & 7.02 & 7.02 & 7.06 & 6.97 & 0.2500 & 0.0001 & 0.0131 & 0.01 & ${ }^{\mathrm{pH}} \hat{y}^{*}$ \\
\hline $\mathrm{N}-\mathrm{NH}_{3}$ & 7.28 & 7.23 & 6.95 & 7.51 & 0.6213 & 0.0577 & 0.0554 & 0.24 & $\hat{y}=7.25$ \\
\hline Urea & 45.87 & 48.05 & 52.96 & 54.76 & 0.0940 & 0.1756 & 0.0540 & 1.43 & $\hat{y}=50.41$ \\
\hline
\end{tabular}

$D$ (diet); $T$ (time); $P$ (statistical probability); SEM (standard error of the mean); RE (regression equation).

$\star{ }^{\mathrm{p} H} \hat{\mathrm{y}}_{0 \%}=7.049-0.0196 \mathrm{X} . \mathrm{R}^{2}=0.6676 . P=0.0295$

${ }^{\mathrm{PH}} \hat{\mathrm{y}}_{66 \%}=7.054-0.1128 \mathrm{X}+0.01408 \mathrm{X}^{2} \cdot \mathrm{R}^{2}=0.9409 \cdot \mathrm{P}=0.0082$

$\mathrm{pH} \hat{\mathrm{Y}}_{33 \%}=7.049-0.0292 \mathrm{X} \cdot \mathrm{R}^{2}=0.8194 . \mathrm{P}=0.0018$

${ }^{\mathrm{pH}} \hat{\mathrm{Y}}_{100 \%}=7.054-0.0828 \mathrm{X}+0.012 X^{2} \cdot \mathrm{R}^{2}=0.9801, \mathrm{P}=0.0224$

An interaction was observed between the proportion of ammoniated babassu palm hay in the diets and the time of collection of rumen fluid post-ingestion (Figure 1), with linear effect with diets of $0(\mathrm{P}=0.0295)$ and $33 \%$ $(\mathrm{P}=0.0018) \mathrm{BHA}_{\mathrm{U} 4 \%}$ and a quadratic effect with the inclusion of 66 and $100 \% \mathrm{BHA}_{\mathrm{U} 4 \%}$ and a tendency to decrease until five hours of collection. This decrease is explained by presence of the diet concentrate in the rumen after feeding, which would increase the production of volatile fatty acids and cause a drop in the $\mathrm{pH}$ of the rumen fluid (Macedo Júnior et al., 2007).

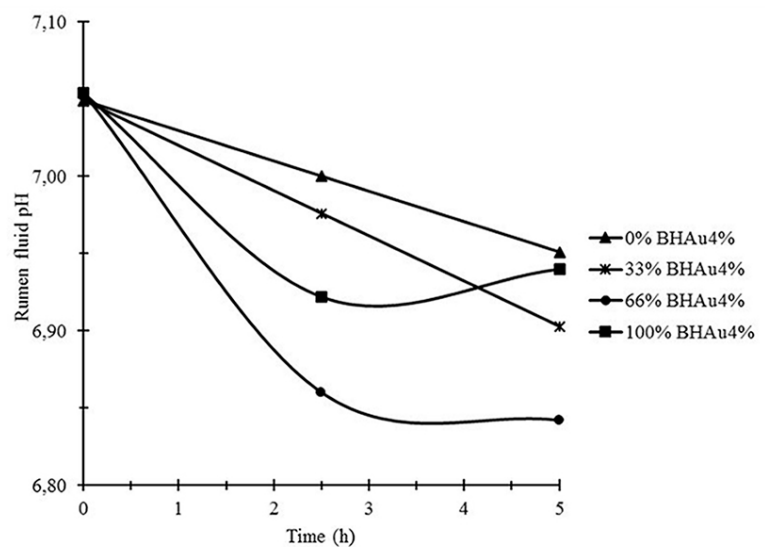

Figure 1: Variation of $\mathrm{pH}$ in the rumen fluid of goats fed diets containing babassu palm hay ammoniated with $4 \%$ urea, as \% DM (BHA $\left.\mathrm{U}_{4 \%}\right)$, substituted for guinea grass hay, according to the time after ingestion.

The inclusion of ammoniated babassu palm hay in diets for maintenance, the collection time and the interaction diet $\mathrm{x}$ time did not influence $(\mathrm{P}>.05)$ the concentration of $\mathrm{N}-\mathrm{NH}_{3}$ in the rumen fluid $\left(7.25 \pm 1.55 \mathrm{mg} \mathrm{N}-\mathrm{NH}_{3} / \mathrm{dL}\right)$ or the concentration of urea in the blood serum $(50.41 \pm 11.04 \mathrm{mg} /$ $\mathrm{dL}$ ) of the goats (Table 6). The value obtained for $\mathrm{N}-\mathrm{NH}_{3}$ was higher than the minimum threshold of $5.0 \mathrm{mg} \mathrm{N}-\mathrm{NH}_{3} /$ $\mathrm{dL}$ of the rumen contents, established by Satter and Slyter (1974) and Moraes et al. (2006), for microbial growth not to be limited in goats and sheep, respectively.

Urea concentrations in the blood serum have been evaluated to monitor compliance with the requirements of $\mathrm{CP}$ intake by animals because excessive intake can cause changes in physiology and reproductive performance and an increased demand in energy and costs. The nitrogen compounds are degraded in the rumen and absorbed by the ruminal epithelium, which are transported to the liver through the bloodstream, where they are synthesised to urea, which may be partly recycled in the rumen via saliva or the epithelium and reused by micro-organisms, while another part is excreted in the urine.

The same effect occurred for rumen fluid $\mathrm{N}-\mathrm{NH}_{3}$ and plasma urea and can be explained because the urea in the serum reflects the $\mathrm{N}-\mathrm{NH}_{3}$ not used by micro-organisms. Mendes et al. (2010) consider plasma concentrations of urea for goats to be elevated when above $24.0 \mathrm{mg}$ urea/dL of blood. These authors report that plasma urea concentration may be altered by various factors such as the content and ruminal degradability of the protein source diet, and they observed higher urea values in the serum of animals fed diets containing urea in its composition.

The plasma urea levels observed in this study are considered high, above $24.0 \mathrm{mg}$ urea/dL of blood, and can be explained by the presence of non-protein nitrogen in the diet in the form of urea or ammonia from the ammoniation, which influences the of urea in the blood serum. However, these values are in agreement with those recommended by Menezes et al. (2006) to maintain sheep in the normal physiological range of 24 to $60 \mathrm{mg} / \mathrm{dL}$. 


\section{CONCLUSIONS}

The intake and digestibility of DM and nutrients are reduced with the inclusion of babassu palm hay ammoniated with $4 \%$ urea in maintenance diets for goats with positive nitrogen balance and stability of rumen $\mathrm{pH}$ and $\mathrm{N}-\mathrm{NH}_{3}$ as well as blood urea, with values within the normal physiological range for goats.

\section{REFERENCES}

AGRICULTURAL AND FOOD RESEARCH COUNCIL - AFRC. Energy and protein requirements of ruminants: $A n$ advisory manual prepared by AFRC Technical Committee on responses to nutrients. Wallingford, UK: Commonwealth Agricultural Bureau International, 1993.

AGY, M. S. F. A. et al. Sunflower cake from biodiesel production fed to crossbred Boer kids. Revista Brasileira de Zootecnia. 41(1):123-130, 2012.

ASSOCIATION OF OFFICIAL AGRICULTURAL CHEMISTS AOAC. OFFICIAL METHODS OF ANALYSIS OF AOAC INTERNATIONAL, $19^{\text {th }}$.ed., Association of Analytical Communities, Gaithersburg, MD, USA, 2012.

BLAXTER, K. L.; CLAPPERTON, J. L. Prediction of the amount of methane produced by ruminants. British Journal of Nutrition. 19(1):511-522, 1965.

BRANCO, A. F. et al. Farinha de penas hidrolisada em dietas de ovinos. Revista Brasileira de Zootecnia. 32(6):14541460, 2003.

BRANCO, R. H. et al. Efeito dos níveis de fibra da forragem sobre o consumo, a produção e a eficiência de utilização de nutrientes em cabras lactantes. Revista Brasileira de Zootecnia. 39(11):2477-2485, 2010.

CALIXTO JÚNIOR, M. et al. Digestibilidade aparente dos nutrients da dieta contend feno de grama-estrela (Cynodon nlemfuensis Vanderyst) tratado com ureia. Acta Scientiarum. Animal Science. 29(2):203-208, 2007.

CARRO, D. M. et al. Urinary excretion of purine derivatives, microbial protein synthesis, nitrogen use, and ruminal fermentation in sheep and goats fed diets of different quality. Journal of Animal Science. 90(11):3963-3972, 2012.

CARVALHO, G. G. P. et al. Valor nutritivo do bagaço de cana-deaçúcar amonizado com quatro doses de ureia. Pesquisa Agropecuária Brasileira. 41(1):125-132, 2006.

CARVALHO, S. et al. Consumo de nutrientes, produção e composição de leite de cabras da raça Alpina alimentadas com dietas contendo diferentes teores de fibra. Revista Brasileira de Zootecnia. 35(3):1154-1161, 2006.
DETMANN, E.; VALADARES FILHO, S. C. On the estimation of non-fibrous carbohydrates in feeds and diets. Arquivo Brasileiro de Medicina Veterinária e Zootecnia. 62(4):980-984, 2010.

GARCEZ, B. S. et al. Valor nutritivo do feno de folíolos de pindoba de babaçu submetido à tratamentos alcalinos. Ciência Rural. 44(3):524-530, 2014.

GOBBI, K. F. et al. Composição química e digestibilidade in vitro do feno de brachiaria decumbens Stapf. Tratado com ureia. Revista Brasileira de Zootecnia. 34(3):720-725, 2005.

LABTEST. Sistema para diagnostic: Ureia. Belo Horizonte: Labtest Diagnóstica S.A, 1999.

LICITRA, G.; HERNANDEZ, T. M.; VAN SOEST, P. J. Standardization of procedures for nitrogen fractionation of ruminant feeds. Journal of Animal Science and Technology. 57(4):347358, 1996.

MACEDO JÚNIOR, G. L. et al. Qualidade da fibra para dieta de ruminantes. Ciência Rural. 17(1):7-17, 2007.

MENDES, C. Q. et al. Substituição parcial do farelo de soja por ureia ou amireia na alimentação de cabras em lactação. Revista Brasileira de Zootecnia. 39(8):18181824, 2010.

MENEZES, D. R. et al. Balanço de nitrogênio e medida do teor de ureia no soro e na urina como monitoradores metabólicos de dietas contendo resíduo de uva de vitivinícolas para ovinos. Revista Brasileira de Saúde e Produção Animal. 7(2):169-175, 2006.

MORAES, E. H. B. K. et al. Avaliação nutricional de estratégias de suplementação para bovinos de corte durante a estação seca. Revista Brasileira de Zootecnia. 39(3):608-616, 2010.

MOREIRA FILHO, M. A.; OLIVEIRA, M. E. de. Composição bromatológica de seis espécies nativas do estado do Piauí consumidas por caprinos. Pubvet. 2(34):1-31, 2008.

NATIONAL RESEARCH COUNCIL - NRC. Nutrient Requirements of Dairy Cattle. $7^{\text {th }}$ rev. ed. Washington, D.C.: National Academy Press, 2001. 381p.

NATIONAL RESEARCH COUNCIL - NRC. Nutrient Requirements of Small Ruminants: Sheep, goats, cervids, and new world camelids. $7^{\text {th }}$ ed. Washington: National Academic Press, 2007. 362p.

NOGUEIRA, A. R. A.; SOUSA, G. B. Manual de Laboratórios: solo, nutrição vegetal, nutrição animal e alimentos. São Carlos: Embrapa Pecuária Sudeste, 2005. 316p. 
SATTER, L. D.; SLYTER, L. L. Effect of ammonia concentration on rumen microbial production in vitro. British Journal of Nutrition. 32(2):199-208, 1974.

SCHMIDT, P. et al. Valor nutritivo do feno de braquiária amonizado com ureia ou inoculado com Pleurotus ostreatus. Revista Brasileira de Zootecnia. 32(6):2040-2049, 2003.

SILVA, D. C. et al. Metabolismo dos compostos nitrogenados em ovinos alimentados com dietas contendo farelo de mamona destoxificado. Acta Scientiarum. Animal Science. 32(2):219-224, 2010.

STATISTICAL ANALYSIS SYSTEM - SAS. Statistical Analysis System User's Guide: Statistics, Version 8. SAS Institute Inc., Cary, NC, USA: SAS Institute Inc, 2002.

VALENTE, T. N. P. et al. Avaliação dos teores de fibra em detergente neutro em forragens, concentrados e fezes bovinas moídas em diferentes tamanhos e em sacos de diferentes tecidos. Revista Brasileira de Zootecnia. 40(5):1148-1154, 2011.
VAN SOEST, P. J. Nutritional Ecology of the Ruminant. 2.ed. Cornell: Cornell University, 1994. 476p.

VAN SOEST, P. J.; ROBERTSON, J. B.; LEWIS, B. A. Methods for dietary fiber, neutral detergent fiber, and nonstarch polysaccharides in relation to animal nutrition. Journal of Dairy Science. 74(10):3583-3597, 1991.

WEISS, W. P.; CONRAD, H. R.; PIERRE, N. R. S. A theoreticallybased model for predicting total digestible nutrient values of forages and concentrates. Animal Feed Science and Technology. 39(1-2):95-110, 1992.

ZANINE, A. M. et al. Efeito de níveis de ureia sobre o valor nutricional do feno de capim-Tânzania. Semina: Ciências Agrárias. 28(2):333-340, 2007.

ZHAO, X. H. et al. Effects of physically effective fiber on chewing activity, ruminal fermentation, and digestibility in goats. Journal of Animal Science. 89(2):501-509, 2011. 